
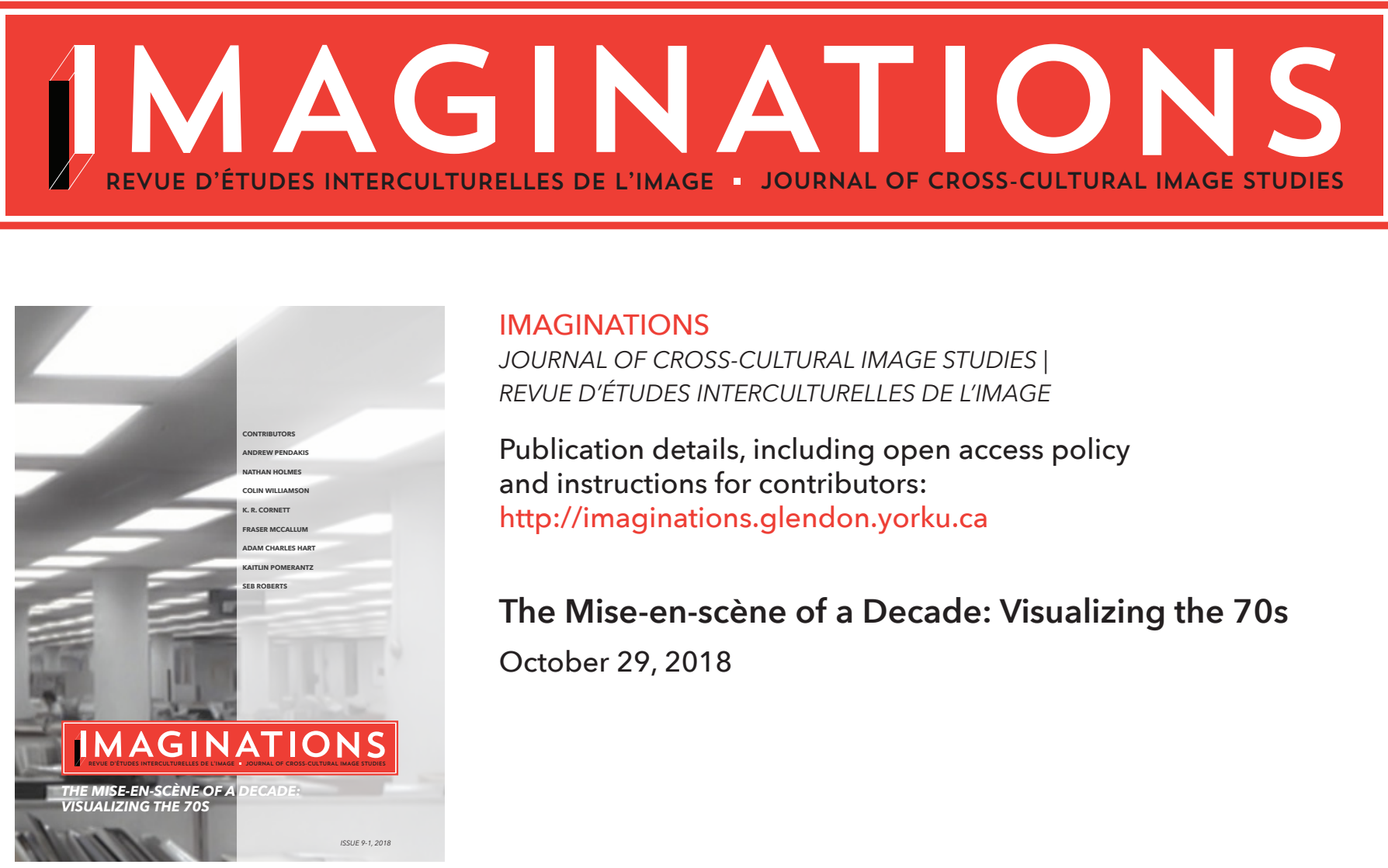

IMAGINATIONS
JOURNAL OF CROSS-CULTURAL IMAGE STUDIES |
REVUE D'ÉTUDES INTERCULTURELLES DE L'IMAGE

Publication details, including open access policy

and instructions for contributors:

http://imaginations.glendon.yorku.ca

The Mise-en-scène of a Decade: Visualizing the 70s

October 29, 2018

To cite this article:

Hart, Adam Charles. "Killer POV: First-Person Camera and Sympathetic Identification in Modern Horror." Imaginations, vol. 9, no. 1, 2018: Web (date accessed), pp. 69-86. DOI 10.17742/IMAGE.p70s.9.1.6.

To link to this article:

http://dx.doi.org/10.17742/IMAGE.p70s.9.1.6

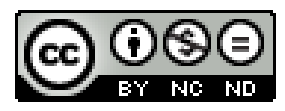

The copyright for each article belongs to the author and has been published in this journal under a Creative Commons Attribution NonCommercial NoDerivatives 3.0 license that allows others to share for non-commercial purposes the work with an acknowledgement of the work's authorship and initial publication in this journal. The content of this article represents the author's original work and any third-party content, either image or text, has been included under the Fair Dealing exception in the Canadian Copyright Act, or the author has provided the required publication permissions. 


\title{
KILLER POV: FIRST-PERSON CAMERA AND SYMPATHETIC IDENTIFICATION IN MODERN HORROR
}

\author{
ADAM CHARLES HART
}

\begin{abstract}
Killer POV-a subjective camera without a reverse shot-is at the center of many of the most influential critical writings on modern horror. However, these discussions often start from the assumption that the camera's point of view produces identification. This essay attempts to disengage our understanding of horror spectatorship from such models and to provide an alternative reading of killer $P O V$ that engages with the genre's structures of looking/being looked at while remaining sensitive to what precisely is being communicated to viewers by these shots. Killer POV signals to the viewer the presence of a threat without displaying the monster/killer/bearer of the look onscreen. In addition to keeping the threat un-embodied (or only vaguely embodied) and unplaced, killer POV alerts the viewer to the film's withholding of crucial diegetic information, both of which are essential to understanding the unique mode of spectatorship provoked by modern horror films.
\end{abstract}

Résumé | Killer POV_caméra subjective sans montage parallèle-est au centre de nombreux articles critiques les plus influents sur le film d'horreur moderne. Ces discussions se basent cependant souvent sur l'idée que le point de vue de la caméra crée l'identification. Cet essai tente de détacher notre interprétation du regard du spectateur sur l'horreur de tels modèles et d'offrir une lecture alternative de killer POV qui implique les structures du regardant/regardé de ce genre de film tout en demeurant sensible à ce qui est exactement communiqué aux spectateurs par ces scènes. Killer POV signale au spectateur la présence d'une menace sans représenter le monstre/tueur/ porteur de cette apparence sur lécran. En plus de garder la menace non-incarnée (ou seulement vaguement incarnée) et physiquement absente, killer POV alerte le spectateur sur le fait que le film retient des information diégéniques cruciales, ces deux fonctions sont essentielles à la compréhension du mode unique de regard provoqué par les films d'horreur modernes. 
Introduction

I $\mathrm{n}$ the 1970s, horror was a genre in flux. Whereas in traditional Western horror narratives monsters such as Dracula came from Old Europe (often preying on New Europe), the descendants of Norman Bates and Romero's ghouls came from next door or from the outskirts of town, happening upon victims thanks to inopportune stops along the highway or more intimate, familiar reasons. Though ghosts and vampires never went away, the genre made room for-and was increasingly identified withmore human monsters. ${ }^{1}$ In the horror films of the 1970 monstrosity shifted to psychological and behavioral categories: you are a monster for what you do, not what you are, for your brain rather than your physiology, supernatural or otherwise. This new wave distinguished itself in part through an emphasis on violence, as horror films became bloody in a way that had mostly existed at the margins of the exploitation circuit before Night of the Living Dead (1968) and The Texas Chain Saw Massacre (1974). This was an era of raw, visceral horror that spawned the first sustained serious critical and academic considerations, most influentially in the writings of Robin Wood, who identified an emerging revolutionary energy in the genre. ${ }^{2}$

As the influence of Psycho (1960) and Night of the Living Dead took hold with films such as Massacre, Last House on the Left (1972), The Exorcist (1973), Sisters (1973), Carrie (1976), Shivers (1976), God Told Me To (1976), and Halloween (1977), horror shifted stylistically alongside narrative and thematic changes, typically in favor of more immediate, visceral aims. Most obviously, this change came through spectacles of violence, but also through documentary-inflected camerawork and an increased reliance on offscreen space. These stylistic shifts were, in part, a reaction to the genre's turn away from traditional monstrosity. When the fearsome spectacle of monsters was no longer the defining trait of horror, the genre found other ways to distinguish itself. Without the otherworldly terrors of ghosts and goblins, what separates a killer with a knife or a chainsaw from, say, a killer with a gun in a gangster movie? The answer was largely formal. If traditional monsters are monstrous because they exist physically at the edges of our realms of understanding, then modern horror sought to make its physiologically human killers sufficiently fearsome and unfathomable through stylistic innovations. Cinematography became crucial to horror's aesthetic and to its creation of threatening, dangerous monsters. Monsters and killers moved offscreen, and lurking, roving cameras signaled to the audience that something was out there watching and waiting to attack.

This transformation becomes formalized and focused through what I call "killer POV." An unattributed subjective camera, killer POV is unique to horror. It places a threat within a scene without visualizing it. The technique was quickly adopted as a method for attributing a sort of unfathomable fearsomeness to the physiologically unexceptional killers of 1970 horror. Killer POV located its threats offscreen, in the unseen spaces surrounding us, just beyond what was visible. It viscerally communicated (and enacted) the paranoid tinge of 1970 s horror: we know the danger is out there, somewhere.

By the early 1980s, the roving, unattributed point-of-view shot was emblematic of horror, but it also became a symbolic punching-bag for much that critics hated about the always disreputable genre. For many critics, killer POV was evidence of a turn away from the rebellious, anti-authoritarian energy that Wood celebrated in 1970 s horror. Whereas the films of the early 
1970 focused on identifying the humanity within their dispossessed monsters and villains, the masked killers of the 1980 offered no such opportunities. To the genre's detractors, killer POV seemed to invite a sadistic celebration of the violence it depicted without humanizing its perpetrators. The resulting critical consensus on this era of the genre has been largely reliant on models of sympathetic identification that assume a conventional, narratively absorptive viewing position. Such analyses, often founded on assumptions taken from the apparatus theorists of the 1970s, suggest that sympathetic identification is decided primarily (or even exclusively) by camera position. ${ }^{3}$ The aim of this essay is to disengage our understanding of horror spectatorship from such models of sympathetic identification in favor of a more flexible understanding based on horror's sensational modes of address. I also

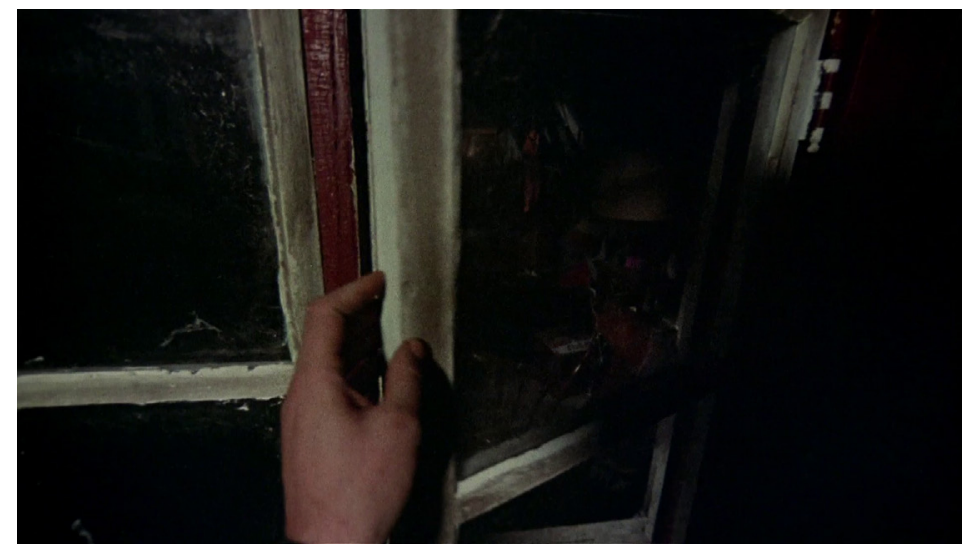

The killer sneaks into a second-story window in Black Christmas. (Warner Bros.) aim to show how sympathetic distance can be created between the spectator and the camera, a separation of the camera's look from the gaze. ${ }^{4}$ Moreover, this essay will work through the meaning of a POV camera within narrative cinema more generally, to dissect precisely what is communicated by an image that represents the vision of a diegetic character.

The Devil's Eyes

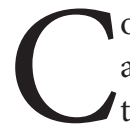
onsider this example: A POV camera approaches a large sorority house from shakier in its movement than it was in the preceding exterior shot. The image cuts between this handheld camerawork and more traditionally (tripod-stabilized) shot and edited scenes of the women inside the house. One stationary insert shot shows the partial silhouette of a man's head as he peers through the window from approximately the same position as the previous handheld shot. This is the closest the film gets to a reverse-shot revealing the bearer of the look. As the camera approaches the side of the house, two arms appear at the edges of the frame and climb, along with the camera, up to a second story window.
This sequence from the beginning of 1974's Black Christmas is an early instance of killer POV, a shot that represents the position and perspective of a character but is distinguished from other POV shots in its refusal of reverse shots and its nearly universal characterization as menacing (or at least suspicious). Black Christmas returns to killer POV repeatedly: the POV camera moves stealthily through the sorority house, sneaking up on its unsuspecting inhabitants for a first-person view of each subsequent attack. For many of the film's attacks, hands will appear at either side of the frame to strangle or stab some unfortunate co-ed. We read the camera as a literal presentation of the killer's perspective: it presents not a general approximation of his position within the scene but, supposedly, 
precisely what he is seeing. First and foremost, it indicates presence.

Variations on this device have been incredibly common in horror since the 1970s. Its instant legibility explains its sustained, widespread use: upon seeing a killer POV shot, the viewer can assume that it represents the position and perspective not just of someone within the scene, but of a specifically malevolent figure. Indeed, the practice was so ubiquitous that horror films quickly became fond of playfully exploiting this assumption, with countless killer POV shots ending in friendly greetings, practical jokes, or leaping cats.

Black Christmas was one of the earliest North American films to employ killer POV extensively. The technique comes less from Hollywood's experiments with the subjective camera in films such as Lady in the Lake (1946) or Dark Passage (1947) than it does from the pioneering Italian gialli of Mario Bava and Dario Argento. Brief killer POV sequences appear in Argento's Bird with the Crystal Plumage (1969) and Bava's Twitch of the Death Nerve (Reazione a catena) (1971). The technique would go on to play a major role in Argento's filmography especially, becoming a major component of later films such as the influential Deep Red (Profondo rosso, 1976) and Opera (1987). In Argento's and Bava's films, killer POV plays a crucial narrative purpose: in many ways, these films follow the narrative structure of mysteries, and killer POV allows attacks (and other scenes in which the murderer plays a role) to be shown on screen without revealing the murderer's identity to the viewer. In that sense, it is a stylistic equivalent of the black gloves and mask of Bava's Blood and Black Lace (Sei donne per l'assassino) (1964) and similarly concealing costuming in Argento's early films. Killer POV also fits in with the complex, virtuosic network of moving camerawork and subjective shots that characterize both directors' work-one type of moving camera among many.

Once the technique spreads through North American cinema, it moves beyond mystery narratives. Although Black Christmas, like the Italian films, has obvious mystery elements, it de-emphasizes them-and, in fact, never reveals the killer's identity. Further, the systematic, extensive use of killer POV in Black Christmas serves an additional function, one that subsequent films will capitalize on even as the remaining mystery-genre trappings fall away. These films recognize that keeping the killer offscreen is essential to maintaining the threatening character of their killers: being offscreen is precisely what makes them fearsome. Although Black Christmas' killer's movements are carefully mapped out within the house (much more so than in many subsequent slasher films), killer POV here creates a sense of near omnipresence. The killer is vaguely located "offscreen" rather than being concretely placed, and there is little sense that he could actually be detected by any of his unsuspecting victims. His identity remains a mystery, but the power of killer POV lies rather in its capacity to create a vague yet urgent sense of threat, one that exists within the scene but that cannot be precisely placed. Killer POV appears alongside the rise of the slasher and its all-too-human villains precisely because it allows films to characterize its threats as being unembodied, non-human, and perhaps even supernatural. ${ }^{5}$ That is, the narrative tells us that an escaped lunatic with a knife is perpetrating the murders, but what we see onscreen is an un-visualized (perhaps even un-visuablizable) force, not limited to a body, human or otherwise. The camera's perspective places it within the scene, but in a way that avoids precise location: the 
threat exists, in essence, offscreen, either behind the camera or otherwise outside the frame.

In Halloween (1978), the bravura opening killer POV sequence grants credibility to the opening attack, in which a young boy attacks his older teenage sister. The delay of this revelation creates a suspenseful curiosity, and there is a frisson of surprise when the young Michael Myers (Will Sandin) is revealed to be the killer. Yet this sequence has little to do with the epistemological tasks of the mystery genre. Shown from a more traditional perspective, the sight of a sixyear-old with a knife presumably becomes much less menacing, perhaps even ridiculous, and the confrontation between brother and sister much less believable. ${ }^{6}$ camera reaches its target, the shot cuts above the water to show the swimmer being painfully tugged from below. Like all of the above examples, this sequence allows for the depiction of an attack without showing the attacker. However, even more so than the later examples, this could hardly be characterized as a mystery: the killer POV belongs, of course, to a shark. Not until the film cuts to the first shot above the water does the viewer get any concrete, visual evidence of the threat that was connected to that moving camera. Yet the shot, which did not have any exact predecessors in mainstream Hollywood (and so is not referring to a recognized convention), is readily legible: a presence is creeping towards the object of some kind of imminent assault, and we quickly associate the camera with not just a

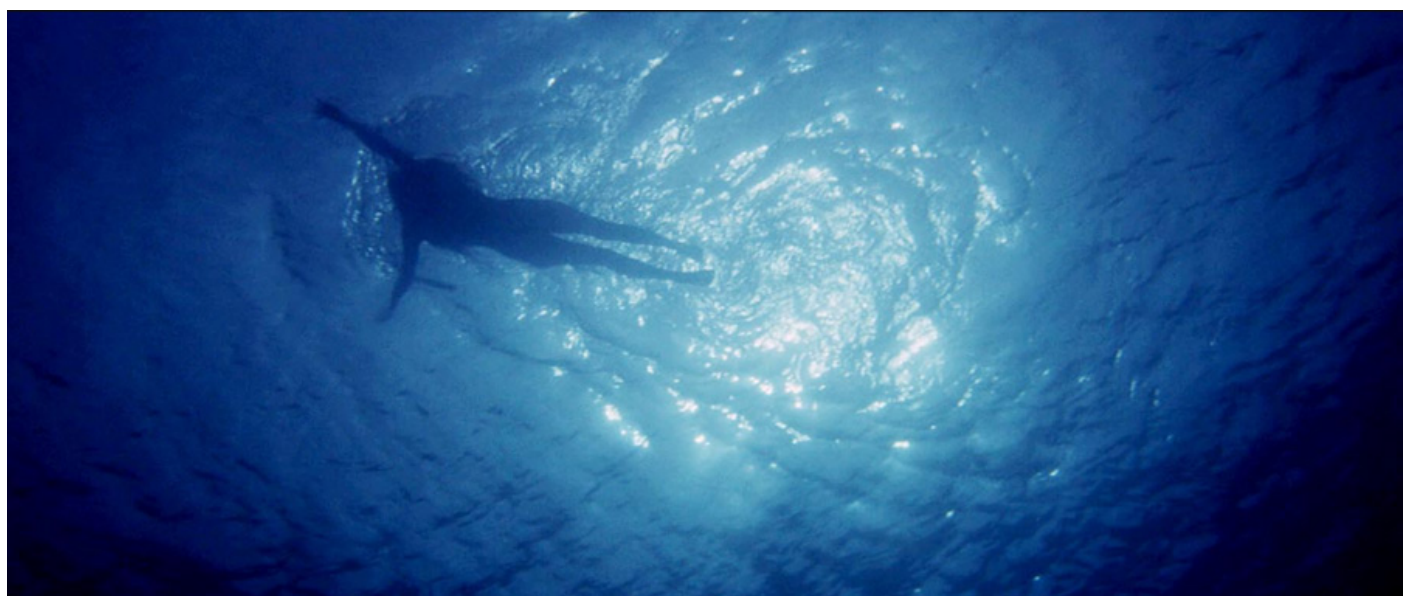

The camera creeps towards a swimmer in Jaws. (Universal Pictures)

Perhaps the most famous, most iconic, and most influential killer POV shots, however, came from outside of the slasher tradition in Steven Spielberg's Jaws (1975). Capping off its celebrated opening scene (and revived again for the film's second attack), a camera moves underwater, angling upwards towards an unsuspecting young woman swimming alone. When the being, but with a malevolent one. As viewers, we realize that when the moving camera reaches its object, something unpleasant will happen to the poor young woman skinny-dipping alone at night. The two killer POV sequences in the film are key to characterizing the villain not simply as a shark, but as an unstoppable killing forceone that is not effectively stopped until the heroes bring it above the water and killer POV is left behind. 
Although its popularity and legibility have led to it being discussed frequently in both academic and popular criticism, writing on horror is marred by an unexamined assumption that killer POV implicates the spectator in the sadistic voyeurism of the monster or killer through whose eyes we are supposedly seeing. According to the standard critical perspective, killer POV constructs-some would even say demands-a position of sympathetic identification with that killer. In his influential essay "Through a Pumpkin's Eye: The Reflexive Nature of Horror," J.P Telotte describes the opening shot of Halloween as having "forced" the viewer to identify with the young murderer (117). However, killer POV can also be understood as working against the kind of sympathetic identification implied there. By sending direct signals to the viewer indicating imminent attack to an onscreen character, it also produces fear for the character's safety. Further, by withholding crucial narrative information in a rather ostentatious manner, killer POV generates a distanciation effect by indicating that we are not privy to some of the scene's most relevant information. Rather than simply aligning the sympathies of the viewer with the killer in the act of looking, I want to argue that killer POV provides a sustained image of that look, a viewing situation that introduces a more complicated series of effects.

Killer POV and Sympathetic Identification

"Point of view = identification," Carol Clover asserts, arguing that the viewer of the typical slasher is "linked, in this way, with the killer in the early part of the film" (45). Roger Ebert famously railed against what he called the "violence against women" film, and killer POV was a key part of his objection. Ebert argued that "it is a truism in film strategy that, all else being equal, when the camera takes a point of view, the audience is being directed to adopt the same point of view," claiming that the films therefore "displaced the villain from his traditional place within the film and moved him into the audience" (55-56). Ebert goes further than Clover, asserting that killer POV implicates the audience and provokes a kind of sadistic voyeurism on the part of the spectator, eliding possible distinctions between a narratorial position and spectatorial sympathies. As perhaps the most influential critic in the United States at the time, Ebert successfully used his national platforms on television and in print to draw significant popular and academic attention to horror's problematic gender politics. Clover, on the other hand, makes room for more nuanced spectatorial positions. In her germinal text, Men, Women, and Chain Saws: Gender in the Modern Horror Film, Clover argues that the viewer's sympathies lie with the monster/killer in the first half (a sadistic perspective), and then, as the "Final Girl" grows more assertive and active, with the heroine in the second (a masochistic one). Both writers' influential accounts assume that visual POV is tantamount to sympathetic identification. Clover examines the flexibility and instability of that position within a single film, and in her discussion of the Final Girl recognizes that there are factors beyond camera position deciding spectatorial sympathies. She privileges and prioritizes identification with the Final Girl, with whom the spectators have developed a more extensive relationship, over the earlier, briefer moments of identification with the pathologized killer. Yet in her account that earlier sympathetic relationship with the killer is based entirely on killer POV (42-64). Throughout the 198 os and early 1990s, critics would continue to account for killer POV's popularity in the genre largely through ideological readings. The most influential accounts of killer POV have understood it to be inviting-again, even 
demanding_-identification with the killer, using it as evidence that horror viewers sympathize with monsters and killers. The implication, of course, is that horror films are sadistic, misogynist, and inciting.

Linda Williams, citing and building on Ebert's argument, similarly attributes malignancy (and an invitation to sadistic sympathies) to killer POV, but re-orients the argument. Williams points out that, in older horror, monsters would often be seen from the heroine's point of view: we see the monster as the victim/heroine sees it, allowing for a "recognition and affinity between the woman and monster" that she claims is an essential element of horror's appeal for female viewers ("When the Woman Looks" 31). Williams examines horror films such as Nosferatu (1922), The Phantom of the Opera (1925), and King Kong (1933), in which the shots of female characters' looking at the monster manifest a sympathetic recognition of otherness. ${ }^{7}$ In modern slasher and slasher-influenced horror films, however, she identifies the monster as a "non-specific male killing force" that "displaces what was once the subjective point of view of the female victim onto an audience that is now asked to view the body of the woman victim as the only visible monster in the film. . . She is the monster, her mutilated body is the only visible horror" (31, original emphasis). While still agreeing with Ebert's basic assumptions, Williams shifts the terms from direct sympathetic identification with the monster to an absence of identification with the victim (still based on camera perspective), and she points out the implications of the victim's body replacing the monster as spectacle. Indeed, in the 1970s and after, horror's primary spectacles begin to shift from terrifying monsters to wounded victims. For all of the nightmares inspired by images of Freddy, Jason, and Michael, the films in which they appear are often dominated more by images of the open, abject bodies of victims than they are by intimidating views of their iconic killers.

These feminist critiques are crucial not just for the history of horror scholarship, but for the history of the genre's productions, as later generations of filmmakers would more fully engage with their substance. ${ }^{8}$ Yet within those critiques, these critics still assume that killer POV causes spectators to identify with the killer rather than the victims. But why would we assume that, in these cases, "point of view = identification"? To be sure, critics have made room for nuance within such accounts. Vera Dika, for example, argues that, because the killer is unseen, the viewer may “identify with the killer's look, but not with his character" (88). However, even Dika's account starts from the familiar presumption of identification. This suggestive assertion of identification with a camera angle has persisted, carrying over into writings on found-footage horror, in which writers such as Barry Keith Grant assert that viewers identify with the diegetic camera (154). ${ }^{9}$

The crucial interventions in the 1970s of the apparatus theorists, particularly Laura Mulvey, provide a useful and durable theoretical model for understanding the inherent ideological content of narrative cinema. Analyzing narrative perspective was of central importance to their project. Mulvey's "Visual Pleasure and Narrative Cinema" claims that classical Hollywood cinema was built on an assumed heterosexual male perspective: men were the active drivers of the narrative, while women functioned primarily to be attained and to be looked at. The look of the camera at female characters/actresses frequently aligned with the look of the male protagonist. Mulvey's critique of Alfred Hitchcock, in particular, depends on the "subjective camera" 
of films such as Vertigo. ${ }^{10}$ Although, as Mulvey notes, most of the shots in Vertigo have at least some relation to the protagonist's POV, we are also shown numerous images of Scottie, the protagonist, looking. We especially see him looking at Madeleine/Judy, the object of his obsessive affections. Thus, while Kim Novak as Madeleine is clearly presented as erotic spectacle to the audience, this perspective is just as clearly marked as belonging to a character within the narrative. In Mulvey's reading, this construction is particularly insidious, illustrating the conflation of the perspectives of male character, male spectator, and camera that characterizes classical cinema.

Writing a little more than a decade later about Mulvey and the Screen school of film criticism, Vivian Sobchack points out that the function of suture-the process of identification with an onscreen character that relies on such classical devices as the shot/reverse-shot construction-is to "disguise the film's perceptual presentation of a representation.... To appropriate the presentational function of the film's perceptive body for the narrative and thus to deny the narrative its dependent status as the expression of a perception by a perceptual authority embodied outside the narrative" (228). What is problematic about this system of representation, Sobchack argues, is that it is not questioned or problematized within the film: the film, in effect, hides its own perspective, naturalizing it as the perspective of characters within a film. Not only does the cinema adopt a voyeuristic position towards eroticized female bodies, it naturalizes that voyeurism.

Killer POV stands out from nearly all other subjective shots in narrative cinema in its insistent refusal to cut to the reverse-shot that traditional suture requires. Rather, it insistently draws attention to itself as a subjective shot. Classical Hollywood-from Hitchcock onwardstends to rely on shot/reverse-shot constructions to indicate perspective. It is through shot/reverse-shot that both literal ownership of the look and, typically, broader sympathies are communicated: the reactions of the looker help to form the sympathetic perspectives of the film itself and, to some degree, the viewer's. By dispensing with the reverse shot, the process of suture that Sobchack describes remains incomplete, and, so too the viewer becomes decoupled from one of the primary mechanisms of identification. If the shot does cut to another angle during a killer POV sequence, that new angle does not reveal the identity, or even the exact placement, of the looker. The film gives no view of the killer's face to cue anything like sympathetic reactions or have a connection of any kind with them as a character.

Further, in many cases the villain, even once revealed, is not exactly a subject; they are, variously, a shark (Jaws), a babbling psychopath (Black Christmas), a blank-faced killer with distinctly robotic movements (Halloween), and so on.. Even though the shark is heavily anthropomorphized-vindictive, even-it is not characterized as a full, coherent subject with whom one might be able to identify. This is not to say that there is no possibility for localized, eventbased (as opposed to character-based) identification. ${ }^{11}$ Undoubtedly, the horror film challenges its viewers in part by soliciting our own, perhaps subconscious, bloodlust. This is, however, not dependent on identification with the person perpetrating violence, and does not preclude any of the other reactions discussed in this essay. That is, that bloodlust can be accessed whether an attack is filmed with killer POV or in a more classical manner. 
Rather than being imbricated within the logic of suture, killer POV abstracts the look, removing it from reference to a familiar or concrete character who is doing the looking. Instead, it presents the act of looking to the audience, and thus should be understood as a depiction of a look. That is, the look itself is just as much the object of the camera's gaze as are the victims-to-be who appear on camera. The camera's look may correspond with that of a character, but there is a rhetorical distinction. Rather than communicating sympathetic alignment, it shows the viewer that, within the scene, someone is looking. Killer POV might align the image of the film with the literal perspective of a character, but if we are invited to sympathize with any character in the shot, it is not obvious that camera position alone should be the decisive factor in producing fear for the victim. Killer POV, rather than being primarily an identification-device, is a device for creating suspense in that it cues us to expect an attack and to wait for it to arrive. For all of their important critiques, Clover, Ebert, and Williams tend to ignore this suspense function because they do not think of horror in terms of its affective communication to the audience: killer POV directly signals the possibility of an attack. As a device, killer POV is only effectively frightening if viewers recognize the danger for characters onscreen. What is disturbing about these sequences is the disparity between the screaming victim and the unseen, emotionally unresponsive wielder of the look: the only emotional cues we are offered come from the object of the look, with a radical separation between the viewer and the person through whose eyes we are looking.

Indeed, killer POV is indicative of horror's shifting priorities, away from sympathetic identification in general (associated with the "absorptive" viewing practices described by the apparatus theorists) and towards more direct affective stimulation, akin to the visual display associated with the cinema of attractions. ${ }^{12}$ The objects of killer POV's look are indeed objectified, but that objectification can itself be horrific. The precise locus of terror in the sequence is associated with impotent screams and futile attempts at resistance. Even when it does not culminate in an attack, killer POV presents an image of the object of the look as powerless, unaware of and unable to control the threatening look directed at them. The fact that those victims were "most often and most conspicuously [girls]" (Clover 33) supports the feminist reading that terror in horror is written on and with female bodies, but does not necessitate a sadistic pleasure taken in the images themselves. The assumption that "point of view=identification" prevents the genre's critics from exploring the possibilities for sympathy- even if it is simply mimetic-with the figures onscreen.

Moving away for the moment from the thorny, much-debated issues of identification, it is possible to identify two essential functions served by killer POV. The first is practical: it allows for an (inexact) insertion of the killer/monster into the scenographic space without putting their body onscreen. This is directly connected to the spectator's estrangement from the look of the camera. What is being communicated most urgently is not a sympathetic closeness to the unseen, often unknown figure that is doing the looking, but, rather, the presence of a threat and the inevitability of attack. Secondly, killer POV helps to set up a relationship between space inside and outside of the frame that is crucial for understanding the formal and affective workings of modern horror. Offscreen space in horror of the 1970 and after is often a space of possibility that can be dangerously unpredictable. This is most visibly evident in the jump scares that punctuate 
modern horror, moments in which something suddenly appears on screen, unexpectedly breaching the edges of the image. ${ }^{13}$ Killer POV is an important element of this, as the killer is characterized as an entity that is not constrained by the limits of the frame.

It is through killer POV and an insistent refusal to offer more than a glimpse of the villain onscreen that otherwise vulnerable human characters become something more intimidating. The physiologically unexceptional villains of Friday the 13th (1980), Prom Night (1980), The Burning (1981) and any number of sequels and imitators violate the logic of time and space in a manner that approaches a sort of spectral omnipresence (while also seeming to attain omniscience and omnipotence), as long as they remain offscreen. Modern horror's sensational address means that the worlds of modern horror often seem to be built backwards, with the audience's perspective dictating the diegetic realm. With killer POV and other techniques to keep the killer out of the frame, there is no onscreen body for the viewer to see, and so, in a very literal sense, it does not exist to be defended against or defeated by characters within the film. As such, the frame around the image seems to have some bearing on the narrative world of the film. Indeed, the modern horror film blurs the distinctions between diegetic and non-diegetic, with the limits of the frame in particular necessitating consideration as a diegetic or quasi-diegetic category.

Unreliable Spaces

$\mathrm{K}$ iller POV does not just communicate the presence of a threat; there is something thing fundamer of context. There are straightforward explanations for this. Perhaps most obviously, this species of POV camera lurks. It peers voyeuristically through leaves and windows, an inherently suspect activity that the device calls attention to: we are seeing an image of this voyeuristic look. Further, the slasher cycle was so famously formulaic and recycled elements from previous films in the genre that any subsequent film is to some extent relying on the association built by Halloween and Friday the 13th between the POV camera and a killer. Crucially, that killer POV is employed in this way because there is something that makes it instantly understood to be malevolent even when it is not directly connected to an actually threatening character (i.e. the joke that ends with a leaping cat). A reverse-shot would reveal the bearer of the look and the space behind the camera, and this unique absence continually reminds audiences that there are large, narratively significant areas in the diegesis that are being withheld from them.

David Bordwell characterizes the space of classical narrative cinema as being governed by predictability; a coherent world is built through predictable revelation of offscreen space (161). The shot/reverse-shot construction is essential to building this coherent, predictable space, revealing those areas that were previously unseen. In other words, shot/reverse shot configurations give the viewer a sense of visual mastery over the film's space by assuring that any and all important elements of the scene will be revealed. In contrast, horror films from the 1970 on onward tend to thrive on unpredictability: the modern horror film forces its audience to realize that they do not know what lies around the corner, or outside the frame, and killer POV, maybe more than any other technique, exposes, even flaunts, just how little the viewer knows about that world. Killer POV starts without indication of who or what may be wielding it (though we are invited to guess) and denies or delays the 
reverse-shot that would communicate that very important information. The reverse shot may come at any second, or it may never come, or it may come too late, but the viewer has no control over this and, as such, is made to realize that inadequacy. The affective response to a killer POV shot arises not just through the anticipated violent end to the shot, but from anxiety over what we might be missing on the other side of the camera.

Killer POV allows the owner of the look the freedom of movement and apparent mastery over space that comes from remaining unseen. At the end of a film, when the tables are turned on the killer, the combined looks of camera and protagonist stabilize them within a more-or-less consistent physicality that can be defended against and even defeated. This marriage of viewer/ protagonist perspective comes in the form of a return to classical shot/reverse-shot constructions, with the protagonist as the bearer of the look at the killer. The diegetic space finally becomes much more predictable at this point, and viewers are subject to more traditional suspense rather than the shocks (and paranoid anticipation) that punctuate the rest of the film. Where the victims had been the objects of the gaze in previous attacks, here the killer has become the object of the gaze of the heroine and the camera working together. The heroic Final Girl of slasher films overcomes the objectification of victims in earlier scenes to assert her own subjecthood, victimizing the killer who once sadistically objectified her. And rather than relying on camera position, that subjecthood is based on traditional cinematic methods of characterization: she is a fully-fledged, psychologically complex, and often heroic, character. Further, we are aligned stylistically with her in much more traditional forms - not simply through a reliance on shot/ reverse shot, but through a surplus of close-ups of the Final Girl.

For the viewer, killer POV works against a spectatorial sense of mastery over the diegesis that is typical of a more classical narrative construction (or of these final climactic sequences). It refers to and activates vast areas of the scenographic space to which viewers are not privy. The only onscreen figures with whom we might sympathize in killer POV sequences are in distress and often about to be attacked. Some films, and some viewers, can of course see this as an opportunity for straightforwardly sadistic viewing, but the marginalized position of the spectator in these scenes, the withholding of important information, and the shocks that come with sudden eruptions into the frame, complicate the ease of taking such a position. The jump scare, a specialty of modern horror, disturbs the safe distance necessary for voyeurism. The shocks and screams and sudden loud noises prompt a different type of viewing, one that is not only self-conscious but unsettled. If sadism implies mastery, then horror's shocks works against it. The film, as Carol Clover reminds us, attacks not just the onscreen victims, but the viewer in these moments, and these attacks can blur the customary distance between spectator and screen while exposing the lack of knowledge they have about the world of the film (202-203). In Clover's terms, we might consider masochism to be more central to the experience of the entire film, from the killer POV-heavy early sequences onward.

Reverse-Shot: Looking at the Monster

W hen offscreen, slasher villains are rarely limited to the constraints of a physical body. Jason, in the first several Friday the 13th sequels, is able to appear 
from the unseen space behind a tree at just the right time to garrote a victim, or to wield his machete, undetected, from just outside the frame. ${ }^{14}$ $\mathrm{He}$ is nearly omnipresent, except for the space within the frame. Killer POV keeps him loosely tethered to scenographic space, but only for the duration of that shot. His sudden intrusion into the frame, the source of the films' most successful shock effects, often punctuated by shrill violins on the soundtrack, is an iteration of the sort of penetration of place with which modern horror seems to be obsessed: the killer is always on the outside of the house, the room, the closet, trying to get in, and of course the villain seeks to pierce the body, the ultimate measure of place, with knives, claws, teeth. ${ }^{15}$ Here I want to suggest that a similar penetration is occurring in films such as those in the Friday the 13th series when the threat suddenly and violently enters into the place of the frame. Whereas in diegetic space protagonists seek to fortify their boundaries, locking doors and putting boards over the doors and windows when possible, here the protagonist's primary protective measure is visual: keeping the monster in one's sights seems to be a necessary condition for survival. In the final scenes of the film, the look of the camera and the look of the protagonist align to stabilize the monster within the frame, to limit the threat to a single, physically stable body.

At the end of the first Friday the 13th, the killer has not been onscreen except for brief glimpses of hands and shoes (and hazy views in long shot). No victims have been able to muster anything resembling a defense until Mrs. Voorhees (Betsy Palmer) introduces herself to Alice
(Adrienne King), the film's Final Girl. Once Mrs. Voorhees is shown onscreen and, shortly thereafter, reveals herself to be the killer, Alice is able to fight back, to run away and, eventually, to kill her attacker. This is in stark contrast to the series of killings in which Mrs. Voorhees had easily dispatched Alice's fellow camp counselors. Equally, once Mrs. Voorhees appears onscreen, her attack is not as instantly effective as it had been in previous instances when a single blow from a weapon was all that was needed to kill a victim. Being onscreen makes her human and vulnerable. 
aware of the presence of a conscious choosing of the framing. Clover notes that the shakiness of POV camera indicates a weakness in its bearer and prefigures their ultimate defeat (186-87). She questions how anyone could take the threat invoked by the POV camera seriously as, she asserts, it always carries with it these connotations.

However, Clover overlooks the structure of killer POV within individual scenes. During the course of a killer POV shot, the bearer of the look is more or less invincible. In a material sense the owner of that look is not fully present within the diegesis to be defended against (and certainly not to be surprised by another character). That is, killer POV suggests a placement in the scene, but it is not until the moment of the attack that they fully and unequivocally enter the diegesis. Again, modern horror films tend to blur the line between formal and diegetic properties in service of sensational effects. Even with its occasional shakiness-Clover makes no distinction between the shakiness of handheld and smoother Steadicam/Panaglide camerawork that would dominate all but the lowest budget films in the 1980s-and the lurking and hiding that it often undertakes, killer POV represents a position of power over the object of the look. This is precisely why the climactic reversal-the alignment of the look of the camera and the look of the protagonist towards the killer-becomes so important in the final act: it limits the killer to a material body and a specific place within the diegesis. Even then, if the killer moves offscreen, those constraints often disappear, as we see, for example, in the final shots of Halloween.

Indeed, killer POV has a specific affective function, unsettling viewers through its insistent withholding of crucial diegetic information. Thus, even when this is a feint or a joke, and even when there is no possible anthropomorphic perspective aligned with it, horror viewers receive consistent reminders of how little they know of the diegesis, how inadequate their perspective on the scene truly is. Horror viewers do not know with certainty what lies outside the frame, and the films insist on that uncertainty and exploit it to shock their viewers. In other words, these viewers are not the transcendent voyeuristic subjects hypothesized in the first wave of theoretical writings on spectatorship. ${ }^{16}$ Viewers of a modern horror film are better understood as being at the mercy of the film itself: they are insistently made aware of not being in a privileged position of knowledge about the diegetic world. Killer POV shows us that horror movies tend to act on viewers.

This effect is essential to a genre that is so emphatically obsessed with looking and being looked at. Clover lays out the centrality of thematized looking for modern horror, but the importance of the look for horror is even more structurally fundamental, going beyond closeups of eyes or instances of voyeurism (see 166168). ${ }^{17}$ The separation between looking and being looked at structures the modern horror film - which, as Clover and Williams remind us, is a deeply gendered divide. Killer POV in particular puts the act of looking on display while rendering the experience of being looked at terrifying and dangerous.

WWhen a film such as Halloween or Friday the 13th reaches its climax and the killer is, at least temporarily, defeated while fixed within the look of both camera and protagonist, it does so with a return to classical shot/reverse-shot constructions and more traditionally predictable characterizations of space. After the many victims being subjected to the killer's look, impotent to protest, the heroine stands in for all of the killer POV's objects by asserting her own 
subjectivity and, crucially, bringing the camera and the viewer along with her. This assertion, along with the subsequent return to order within the narrative, is marked by a reinstatement of classical formal principles. It is in the final sequence that horror most closely resembles the films of any other genre: even as the excitement and suspense builds in a final showdown, horror's shock-oriented unpredictability is suppressed. Thus, at the moment that the heroine asserts her subjectivity, viewers find themselves in a more traditionally privileged spectatorial position.

Horror's lack of reverse-shots, however, have taken new forms in the past decade with the rise of diegetic cameras in the so-called "found-footage" films. This sub-genre is built around a different kind of POV camera, with a gaze associated with protagonists and victims rather than villains. Each film's images are supposedly those captured by a camera within the world of the film. The style goes back to the notorious pseudo-documentary Cannibal Holocaust (1980), but grows more prominent with 1999's The Blair Witch Project and then, nearly a decade later, Paranormal Activity (2007), Cloverfield (2007), and a proliferation of films in the subsequent years. This is a sub-genre predicated on tragic endings: someone within the narrative uses a camera to record something strange or threatening and, eventually, that threatening something attacks and kills the cameraperson.

The distinction between killer POV and the diegetic camera of found-footage films is immediately apparent. Although they sometimes look similar onscreen, the former signifies an unplaced, vaguely defined malevolent presence, while the latter very specifically places the cameraperson, usually a protagonist. ${ }^{18}$ There is still unpredictability in these images, but unlike killer POV this unpredictability comes not from who and what is behind the camera but from the limits of the diegetic camera's view onto the world. Whereas killer POV indicates something approaching invulnerability and omniscience, the diegetic camera signifies utter vulnerability because neither the viewer nor the cameraperson-whose views are here aligned-know what exists beyond the edges of the frame: we do not know who else might be looking or where they might be looking from. If Killer POV presents a mediated perspective on the diegesis that is only partially placed within that diegesis (and therefore only partially restricted by its physical rules), the handheld camera images of found-footage films, reliant on technologically mediated vision, show characters fully placed within the world of the film.

This upends the logic of killer POV. Here, the bearer of the look is vulnerable precisely because they (however, notably almost exclusively masculine ${ }^{19}$ ) are looking. The spectatorial position coincides with that of the camerapersonat least in scenes in which the camera is being wielded-in that both are searching unfamiliar, unseen territory for potential threats, and both are reliant on a mediated view that is always inadequate. The task of the cameraperson both within the film and as the spectator's avatar is to do their best to compensate for that inadequacy, to attempt to achieve the sort of mastery over filmic space typical of the owner of the look in killer POV, or of the camera in classical Hollywood cinema ${ }^{20}$. However, this is not to say that there is a strong sympathetic identification with the cameraperson, who is rarely the protagonist of the film. By primarily remaining behind the camera, the cameraperson tends to be a cipher; the people the cameraperson films are more fully developed characters and tend to be the ones driving the action. The onscreen 
characters are usually in the same dire situation as the cameraperson: vulnerable and impotent to defend against an unseen entity potentially lurking just off frame, with the spectator being left similarly vulnerable to sudden intrusions from the corner of the frame. ${ }^{21}$ This, however, inspires a different order of identification than the one being discussed by Clover, Williams, or Mulvey. Rather, this is situational and sensational, coming less from close acquaintance with a character than from the spectator being placed in a similarly exposed situation: by looking at the movie, the spectator is subjecting him or herself to the kinds of attacks that result in jumps and screams. Thus, although the meaning of the POV shot has been completely reversed, found-footage's diegetic cameras arise from the same approach to offscreen space.

Found-footage brings to the forefront the genre's anxieties about the look and looking. The shaky camera of found-footage makes the vulnerabilities of the viewer, subjected to the genre's shocking, horrifying images, the explicit text of the film. It aligns the viewer with the owner of the look, the cameraperson's onscreen compatriots cueing our emotional reactions along with whatever commentary the cameraperson might offer. But the anxieties that found-footage thematizes are already present in killer POV, which always implicitly contrasts the omnipotent look of the killer with the partial, vulnerable looks of both viewer and victim.

In horror, the look is a hotly contested arena, for characters as well as for viewers, and spectators have no assurance of control over or safety from the images in front of them. When the slasher film and its descendants reinstate classical formal norms in their climactic scenes, the image becomes more reassuringly predictable.
Found-footage, however, rarely leaves its structuring principle of the diegetic camera, and order is never restored, with film after film ending tragically as the killers/monsters emerge triumphant from their confrontations with camera-wielding protagonists for whom the act of looking is both their only hope for survival and, at some level, what makes them vulnerable. Whereas films reliant on killer POV ultimately, eventually adopt more traditional cinematic forms to reassure their viewers that the vulnerability of their own look can be overcome, that their subjectivity might indeed be asserted against the dehumanizing violence of a monster's gaze, found-footage horror's diegetic camera thoroughly reinforces our feelings of vulnerability. In doing so, it deflates any expectations of--or aspirations towards-mastery or control that we as viewers may yet harbor. What is lost in this transition to a new mode is a sense of contrast: the wielder of killer POV asserts precisely that sort of mastery over the objects of the look, but also draws a clear distinction with our own lack of power. In the end, killer POV suggests precisely the opposite of what its detractors claim: it shows the inadequacy of our own looks in comparison with those of the monsters and killers controlling the camera's perspective. It is not that we have no choice but to identify with these figures, but rather that our helplessness to combat their control of the image is itself a source of horror.

\section{Works Cited}

Benson-Allott, Caetlin. Killer Tapes and Shattered Screens: Video Spectatorship from VHS to File Sharing. University of California Press, 2013.

Bordwell, David. Narration in the Fiction Film. University of Wisconsin Press, 1985. 
Chion, Michel. The Voice in Cinema, trans. Claudia Gorbman. New York: Columbia University Press, 1999.

Clover, Carol. Men, Women, and Chain Saws: Gender in the Modern Horror Film. Princeton University Press, 1992.

Diffrient, David Scott. "A Film Is Being Beaten: Notes on the Shock Cut and the Material Violence of Horror." Horror Film: Creating and Marketing Fear, edited by Steffan Hantke. University Press of Mississippi, 2004, pp. 52-81.

Dika, Vera. “The Stalker Film, 1978-81." American Horrors: Essays on the Modern American Horror Film, ed. Gregory Waller. University of Illinois Press, 1987, pp. 86-101.

Ebert, Roger. "Why Movie Audiences Aren't Safe Anymore," American Film, March 1981, pp. 54-56

Galloway, Alexander. Gaming: Essays on Algorithmic Culture. University of Minnesota Press, 2006.

Grant, Barry Keith. "Digital Anxiety and the New Verité Horror and SF Film." Science Fiction and Television, vol. 6, no. 2, 2013, pp. 153-174.

Hart, Adam Charles. "The Searching Camera: First-Person Shooters, Found-Footage Horror, and the Documentary Tradition." The Journal of Cinema and Media Studies, Forthcoming 2019.

Hills, Matt. "An Event-Based Definition of Art-Horror," in Dark Thoughts: Philosophic Reflections on Cinematic Horror, eds. Steven Jay Schneider \& Daniel Shaw. Lanham, Md: Scarecrow Press, 2003, pp. 138-157.

Hodge, James Joseph. "Gifts of Ubiquity." Film Criticism, vol. 39, no. 2, 2014-15, pp. 53-78
Lowenstein, Adam. Shocking Representations: Historical Trauma, National Cinema, and the Modern Horror Film. Columbia University Press, 2005.

----- "Spectacle Horror and Hostel: Why 'Torture Porn' Does Not Exist." Critical Quarterly, vol. 53, no. 1, 2011, pp. 42-6o.

Metz, Christian. The Imaginary Signifier: Psychoanal$y$ sis and the Cinema, trans. Celia Britton, Annwyl Williams, Ben Brewster, and Alfred Guzzetti. Indiana University Press, 1982.

Mulvey, Laura. "Visual Pleasure and Narrative Cinema." Screen, vol. 16, no. 3, 1976, pp. 6-18.

Paul, William. Laughing, Screaming: Modern Hollywood Horror and Comedy. Columbia University Press, 1994.

Shaviro, Steven. The Cinematic Body. University of Minnesota Press, 1993.

Sobchack, Vivian. Address of the Eye: A Phenomenology of Film Experience. Princeton University Press, 1992.

Spadoni, Robert. Uncanny Bodies: The Coming of Sound Film and the Origins of the Horror Genre. University of California Press, 2007.

Telotte, J.P. “Through a Pumpkin's Eye: The Reflexive Nature of Horror." American Horrors: Essays on the Modern American Horror Film, edited by Gregory Waller. University of Illinois Press, pp. 114-128.

Williams, Linda. "Film Bodies: Gender, Genre, Excess." Film Theory and Criticism, edited by Leo Braudy and Marshall Cohen. Oxford University Press, 2002, pp. 727-741. 
---. "When the Woman Looks." Dread of Difference: Gender and the Horror Film, edited by Barry Keith Grant. University of Texas Press, 1996, pp. 15-34.

Wood, Robin. "An Introduction to the American Horror Film," in Planks of Reason: Essays on the Horror Film, eds. Barry Keith Grant \& Christopher Sharrett. Scarecrow Press, 2004, pp. 107-141.

Zinoman, Jason. Shock Value: How a Few Eccentric Outsiders Gave Us Nightmares, Conquered Hollywood, and Invented Modern Horror. Penguin Books, 2012.

\section{Notes}

1 As chronicled in Jason Zinoman's Shock Value: How a Few Eccentric Outsiders Gave Us Nightmares, Conquered Hollywood, and Invented Modern Horror, the shift to more human monsters was a willful decision on the part of the filmmakers, who loved the horror movies they grew up on but wanted to avoid the cheesiness of their monsters.

2 Wood wrote several articles throughout the 1970s, culminating in his foundational "An Introduction to the American Horror Film," originally published in 1979.

3 Most prominently, Carol Clover (1992) and Linda Williams (1996, 2002), discussed below.

4 Horror has been a fertile forum for such explorations, with scholars such as Linda Williams (2002), Adam Lowenstein (2005), Robert Spadoni (2007), and Steven Shaviro (1993) providing accounts of horror spectatorship that have proven influential outside of the genre as well.

5 The effect is not unlike that of the acousmetre as described by Michel Chion in The Voice in Cinema.

\section{Image Notes}

Figure 1 The killer sneaks into a second-story window in Black Christmas. (Warner Bros.)

Figure 2: The camera creeps towards a swimmer in Jaws. (Universal Pictures)

Figure 3: The killer-Mrs. Voorhees (Betsy Palmer)reveals herself in Friday the 13 th. (Paramount Pictures)

For Chion, the offscreen voice of a not-yet-visualized character achieves properties of "ubiquity, panopticism, omniscience, and omnipotence" (23). The acousmêtre's "powers" come from having one foot in the diegesis, while the other remains in the areas of possibility offscreen. Killer POV similarly places its wielder partially in the diegesis while keeping them unvisualized-and it is no coincidence that it is not uncommon for Killer POV to be augmented with the wielder's breath on the soundtrack, turning them into literal acousmêtres.

6 William Paul makes a similar observation of the film The Bad Seed (1956), in which the crimes perpetrated by a young girl are kept off camera (275).

7 Williams sees the monsters of classical horror films as representatives not of excessive or monstrous masculine sexuality (a common reading of horror), but, rather, the "feared power and potency of a different kind of sexuality (the monster as double for the women)" ("When the Woman Looks" 20).

8 Most directly, Scream [1996] references Clover's ideas, but films such as The Descent [2005], You're Next 
[2011], A Girl Walks Home Alone at Night [2014], and The Love Witch [2016] are equally built on feminist responses to the genre.

9 For a more thorough discussion of POV and found-footage, see Hart.

10 Mulvey writes, "In Vertigo, the subjective camera predominates. Apart from one flash-back from Judy's point of view, the narrative is woven around what Scottie sees or fails to see. The audience follows the growth of his erotic obsession and subsequent despair precisely from his point of view" (16). Note the elision of subjective camera and "point of view."

11 See Hills for a related discussion of what he calls an "event-based definition" of the horror genre.

12 Adam Lowenstein (2011) has discussed certain modes of horror as inheritors of the cinema of attractions in his essay on "spectacle horror." Lowenstein is there concerned with displays presented directly to the viewer, while I am arguing for a more totalizing understanding of horror's direct address.

13 For more on "shock cuts," see Diffrient.

14 Jason was played by a different actor in each Friday the 13th film until Friday the 13th Part VII: The New Blood (1988), the first of four films in which Kane Hodder plays the role.

15 The soundtrack's debt to Bernard Herrmann's Psycho score is apparent throughout both this film and its predecessor in the series, but never more so than during attack scenes that mimic the famous violin shrieks of the Psycho shower scene.

16 See Hodge for a nuanced re-reading of Christian Metz's original essays disputing the conventional reading of his account of the cinematic spectator as "transcendent subject." Whereas the received version of Metz tends to assume he is describing a literal transcendence of bodily awareness, Hodge argues that Metz instead asserts the impossibility of this aspiration. Per Hodge, Metz's arguments are founded on the spectator's awareness of their body.

17 Perhaps the most intriguing response to Clover has come from Caetlin Benson-Allott, who refigures Clover's focus on looking into an analysis of what she reads as horror's anxieties about movie piracy.

18 Alternatively, the found-footage places the camera itself. Although the Paranormal Activity films rely heavily on handheld camerawork, they all extensively use static, surveillance-style cameras on tripods or mounted to ceilings (or, in a particularly ingenious sequence in $P A$ 3, to the motor of a jerry-rigged rotating fan). These surveillance cameras generally indicate an impotent viewing: always seen after the fact, if at all, and there is no human agent associated with that look to intervene. Many of these surveillance scenes occur when the central characters are asleep, so no active looking or alignment between character and camera is even possible.

19 The most notable exception is Patrick Brice's Creep 2 (2017), in which the cameraperson is played by filmmaker Desiree Akhavan.

20 In this sense, found-footage horror is similar to the screen of the First-Person Shooter (FPS) video game. Alexander Galloway's writings on the FPS and its resonances with uses of the subjective camera in film unfortunately predates the recent blossoming of diegetic cameras in horror and elsewhere, and these films do not fit within his taxonomy (39-69).

21 As Caetlin Benson-Allott suggests, in found-footage horror films, the act of looking is not only dangerous, but is often punished. (167-202). 